Technical Capability Building in Shell

\title{
Roland Gelling
}

Global Manager Sub-Surface Learning

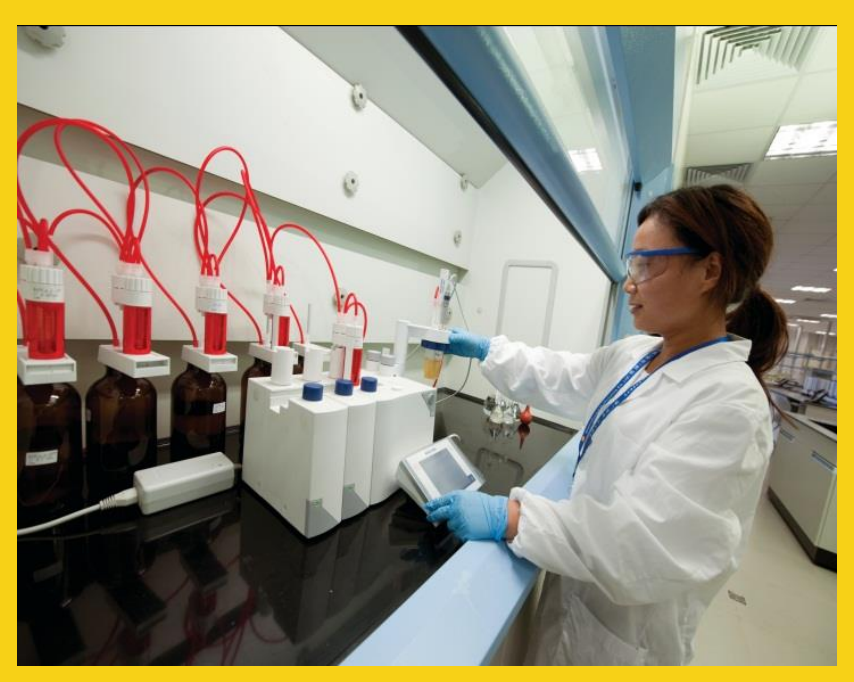




\section{(1) COMPANY PROFILE}

- We are active in more than 70 countries

Worldwide, we employ 87,000 full-time employees

Our fuel retail network has around 43,000 service stations

Each day we produce 3.3 million barrels of oil equivalent

- In 2012, we generated earnings* of $\$ 27$ billion

We spent $\$ 29.8$ billion on net capital investment

- We spent $\$ 1.3$ billion on $\mathrm{R} \& \mathrm{D}$

- Royal Dutch Shell plc is a UK company, with its headquarters in The Netherlands

- We are listed on the stock exchanges of Amsterdam, London and New York

- Shell now produce more gas than oil

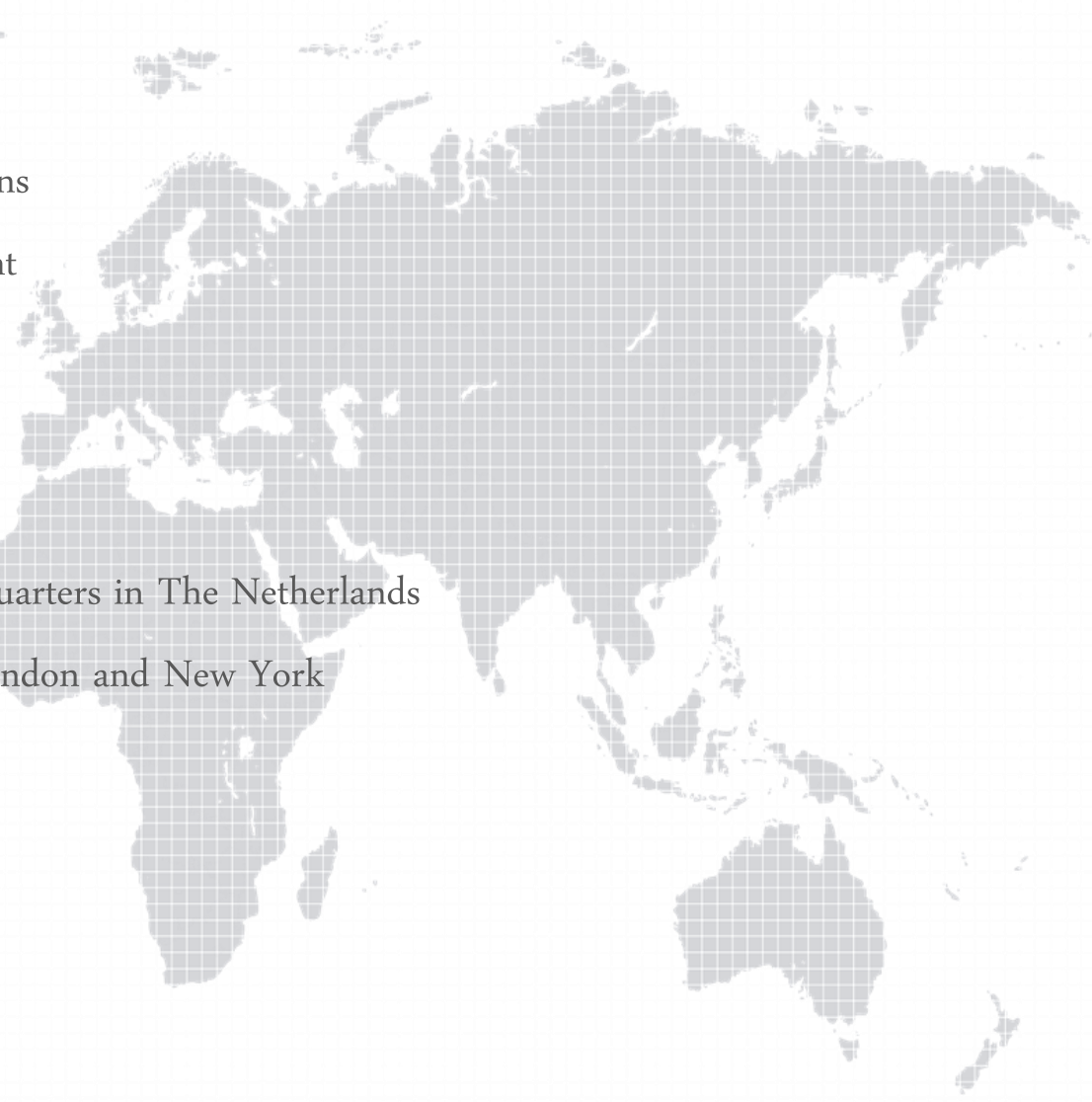




\section{THE ENERGY CHALLENGE}

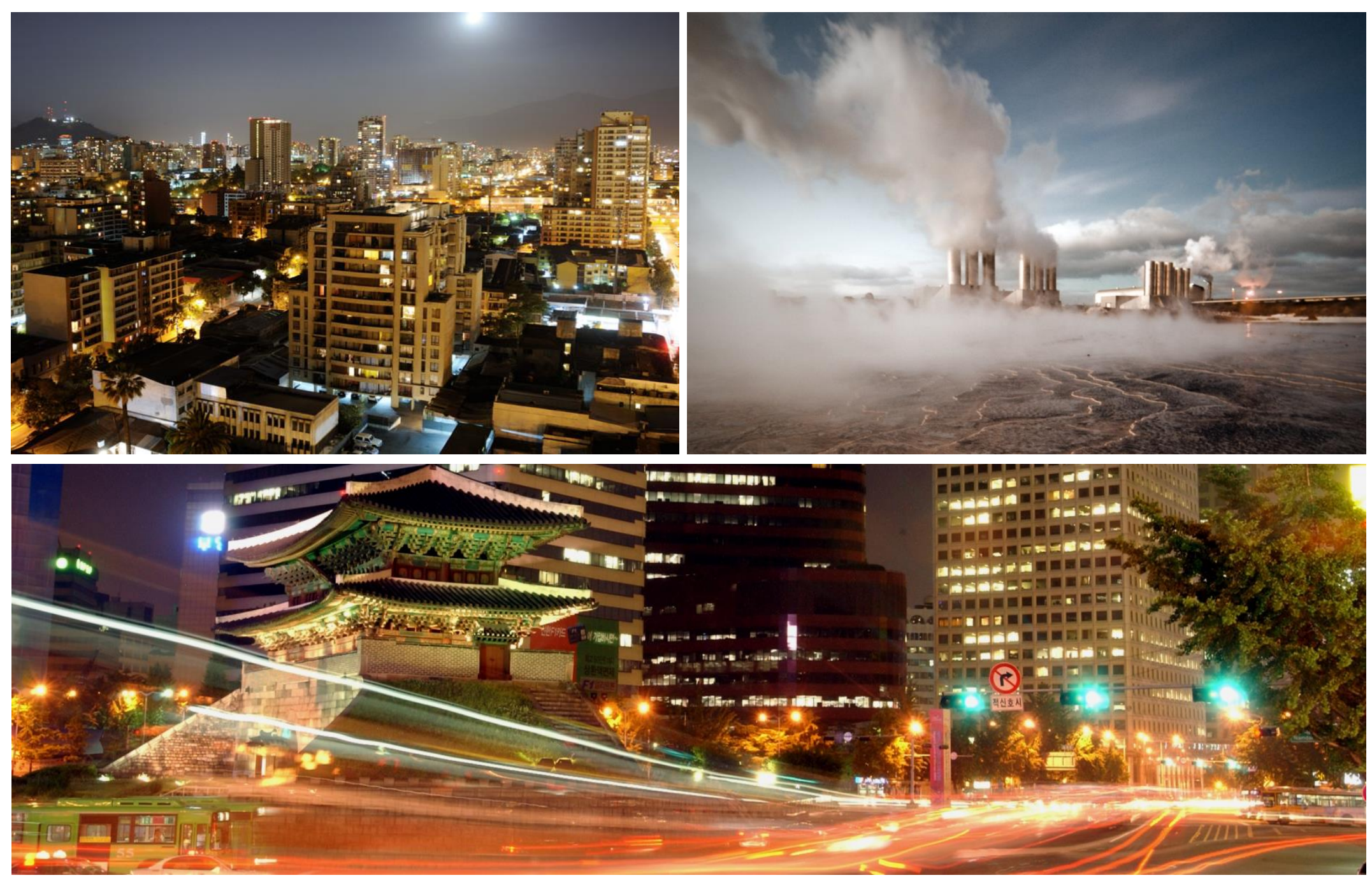




\section{TECHNOLOGY UNDERPINS OUR ABILITY TO UNLOCK CHALLENGING}

\section{HYDROCARBONS}
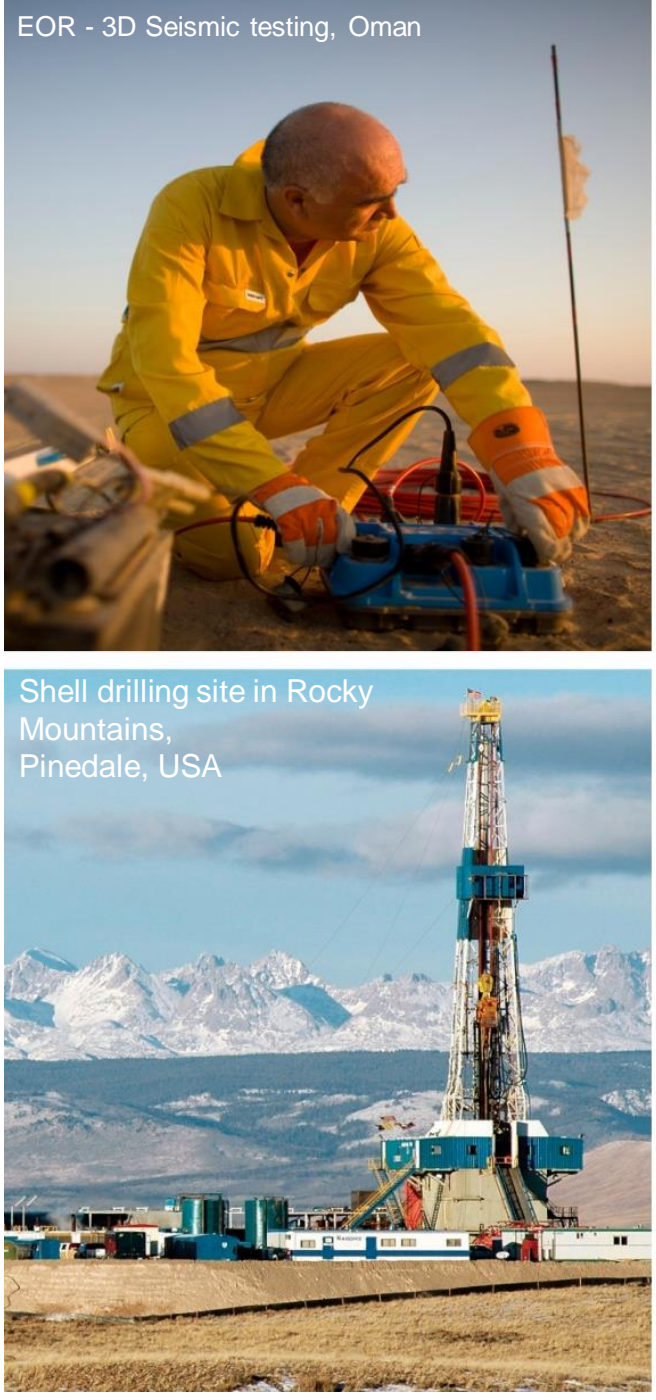
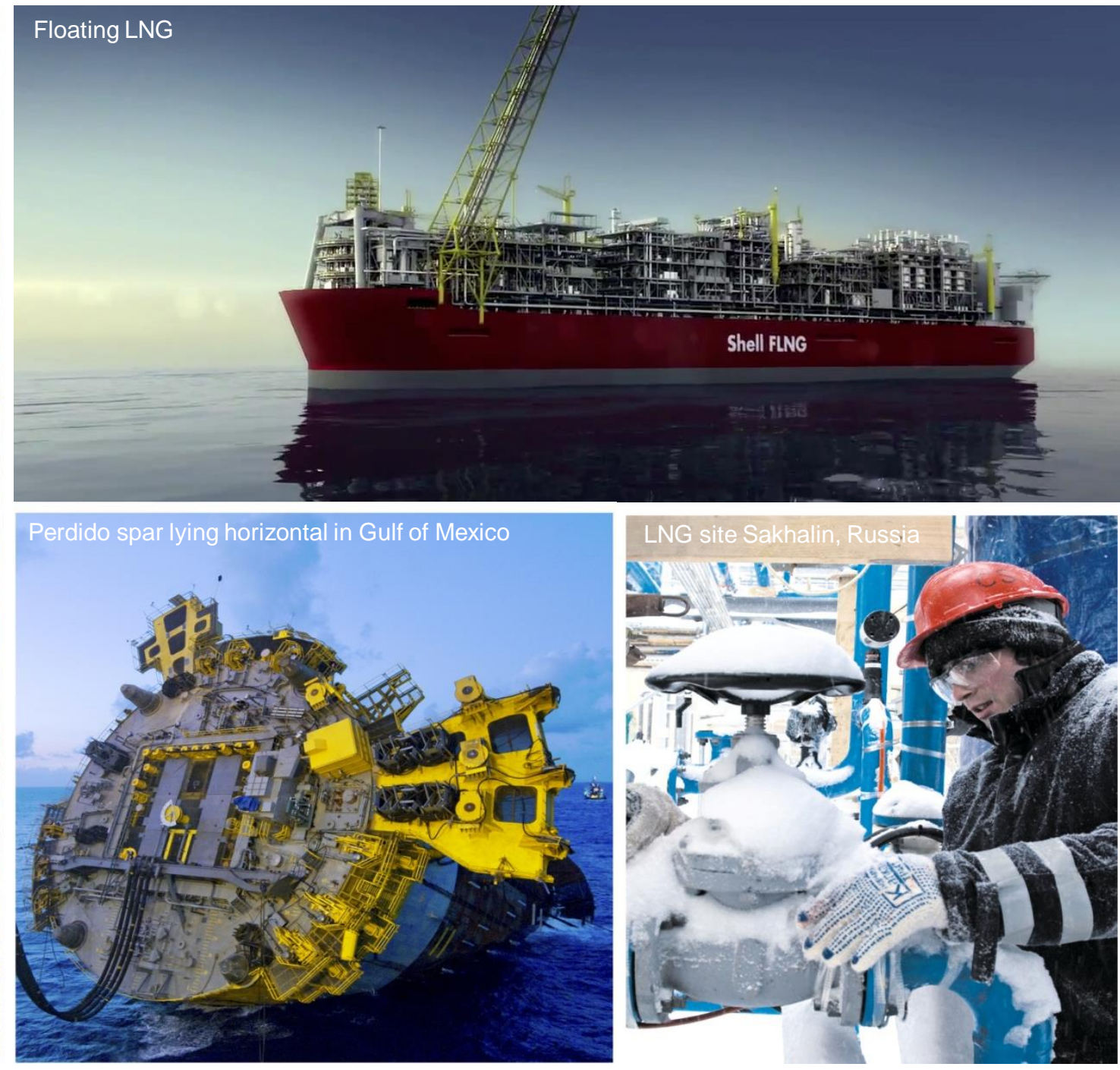


\section{RECRUITMENT GLOBALLY, LANGUAGE POLICY}

- Shell Recruit Globally

- Recruitment in all countries

- University visits for recruitment purposes are targeted in countries of operations

— and in countries where we can find talented educated staff

- Shell workforce should reflect customer base, which means we currently see a shift to the East

- Speaking sufficiently good English is a pre-requisite to joining Shell

- However, in JV situations where Shell assume operatorship, the main language can be different and training programmes may have to be done in other languages

- Language training is offered locally in all Shell companies 


\section{JOINING SHELL - ROUTES INTO SHELL}

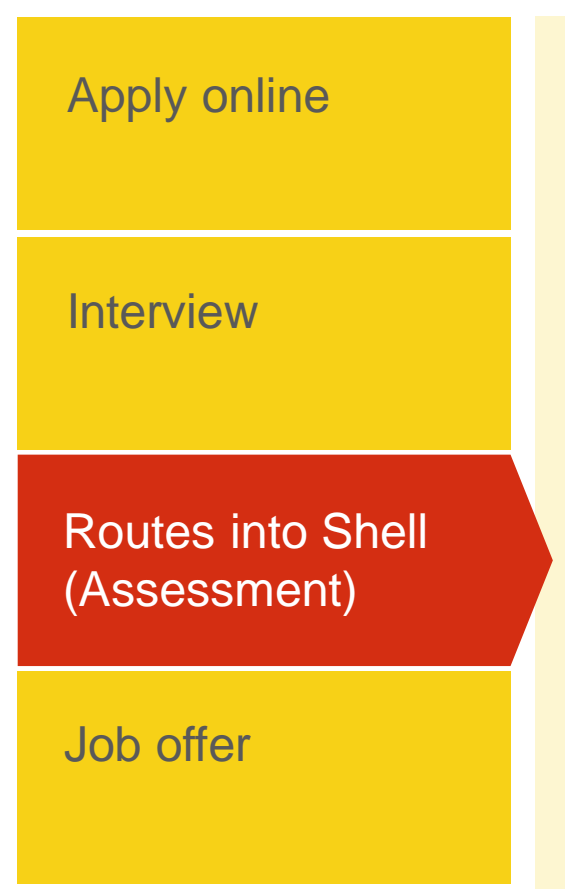

- SHELL RECRUITMENT DAY:

This one and a half day includes:

- Briefing

- Dinner with young Shell graduates

- Case Study

- A group discussion

- Technical presentation or technical interview

- Commercial Business scenario interview

- INTERNSHIP

- Variety of projects from minimum 8 weeks - 1 year

- You will be working on real-life projects (business or graduation thesis)

- Daily interaction with Shell managers who will evaluate your efforts and provide you with valuable performance feedback 


\section{ENTRY INTO COUNTRIES, MOBILITY \& DEPLOYMENT}

When entering a country without a (large) oil/gas industry, Shell

- Initially bring in an expat crew to start the operation

Recruit in country and educate the local staff

- Support local content targets of countries and we support the drive for transfer of knowledge to the local workforce

This requires Shell to have a mobile workforce

- An Expat terms arrangement (salary, housing, schooling)

Managed Open Resourcing system

- Web-based job market

- 3 Rounds per year

— Managed by Skillpool Managers

- Priorities set by top leaders on jobs posted and allocation of staff

- Staff posting window agreed between individual and supervisor

- Placements by exception necessary, in discussion with individuals 


\section{INVESTING IN LEARNING}

\begin{tabular}{|c|}
\hline Staff \\
\hline Training Days \\
\hline Costs \\
\hline Learning Staff \\
\hline Satisfaction \\
\hline Refresh or new training \\
\hline Learning Centres \\
\hline Local/regional delivery \\
\hline
\end{tabular}

$$
87,000
$$

600,000 to 700,000

ca $\$ 300 m$

580

$4.0+$ out of 5.0

$10 \%$ annually

\section{0}

$60-70 \%$
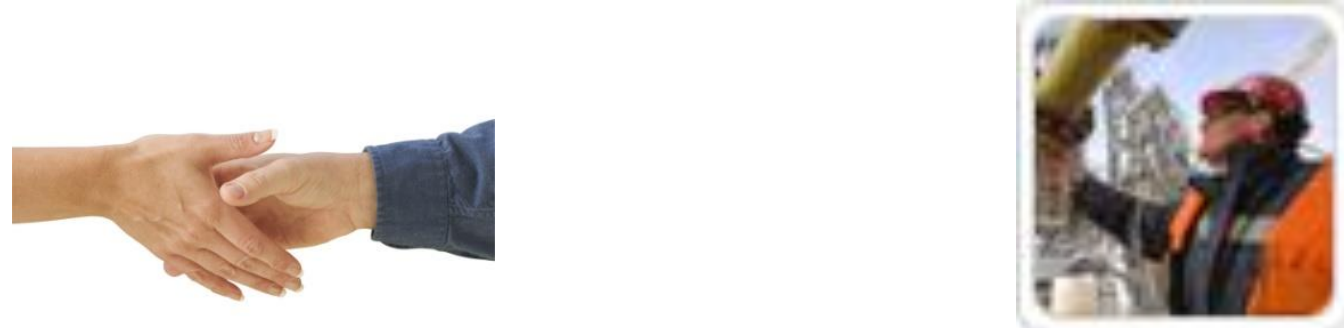

Growing our Business and Talent

Our License To

Safety 


\section{SHELL LEARNING FACULTIES}

Technical Learning:

- Production Academy

- Shell Project Academy

- Discipline and Process Engineering Faculty

- Integrated Business Faculty

- Well Engineering Faculty

- Sub-Surface Faculty

Contracts \& Procurement Faculty

- HSSE, SP \& SD Faculty

— Design \& Development of Learning

Corporate Learning:

- Commercial Academy

- Enterprise Learning Faculty (Leadership, Organisational Effectiveness)

— Finance Learning

— IM/IT Learning 


\section{DIMENSIONS SUB-SURFACE LEARNING PORTFOLIO:}

Portfolio Covers: Reservoir Engineering, Petrophysics \& Geomechanics, Production Geology, Geophysics, Exploration Evaluation, Geomatics \& Data Management

- 11 Full-time Learning Advisers and hundreds of technical lecturers from business

100 Global (plus 70 Local/Regional) Shell Courses ; 345 class events in 2013

— Large Enhanced Oil Recovery and Unconventionals events

— 16000 Training Person Days in 2009 ; 35000 TPDs in 2013

- Cost per training-person-day $<\$ 500$ for courses, including investment recovery

Limited use of External Providers:

$\begin{array}{ll}\text { - Nautilus } & 2 \% \\ - \text { PetroSkills } & 3 \% \\ \text { - IHRDC IPIMS } & 3 \%\end{array}$

- Others $\quad 2 \%$

- 10+ courses in development every year ; Shell Design Team, Accenture \& NIIT

— Currently $89 \%$ Blended ; e-learning used as part of blended events, in pre-work 


\section{BLENDED LEARNING APPROACH}

\section{Blended Learning:}

Integrating formal and informal learning through work-based activities

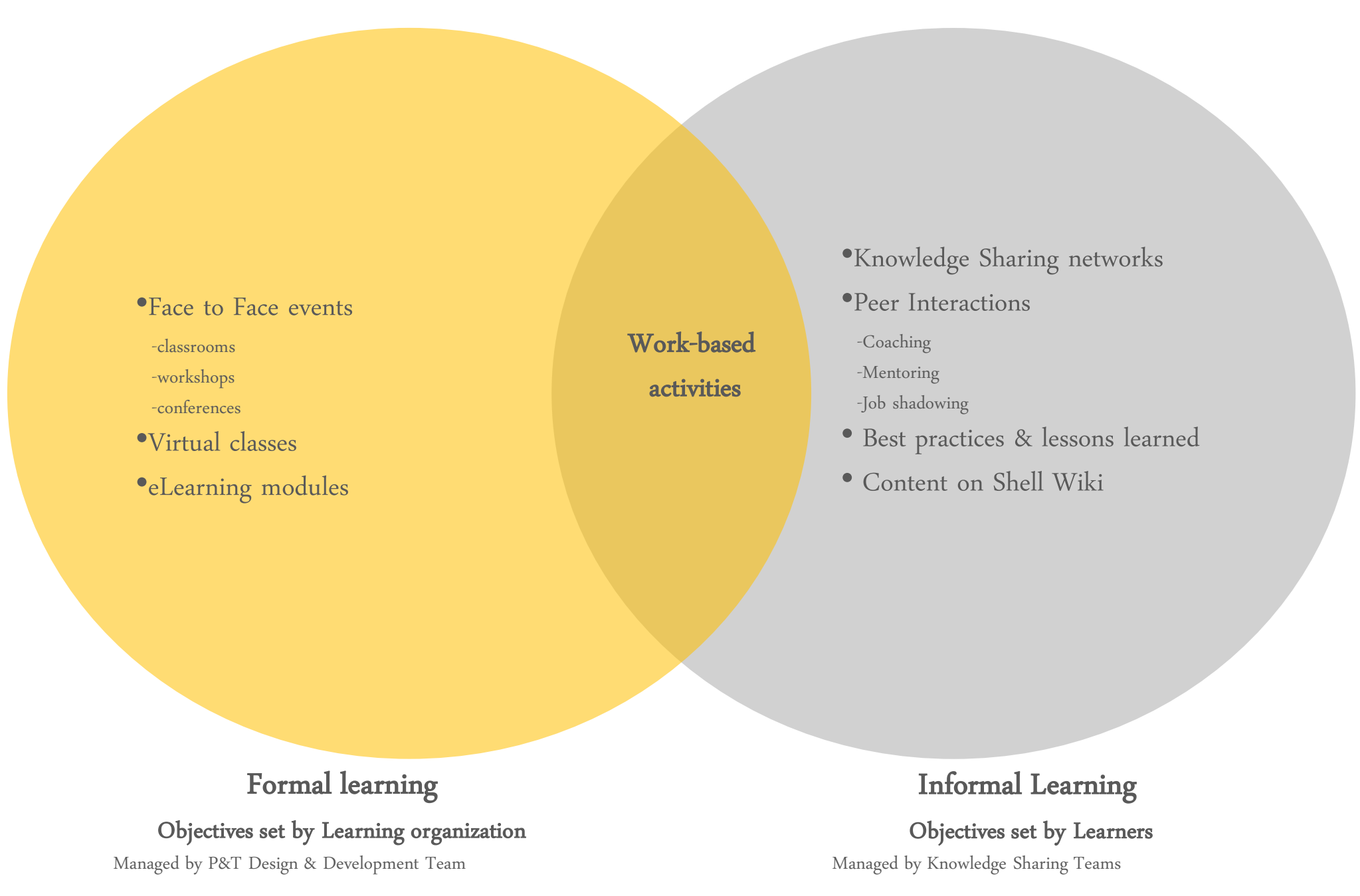


DEMOGRAPHIC CHALLENGE: Petroleum Engs and Geoscientists
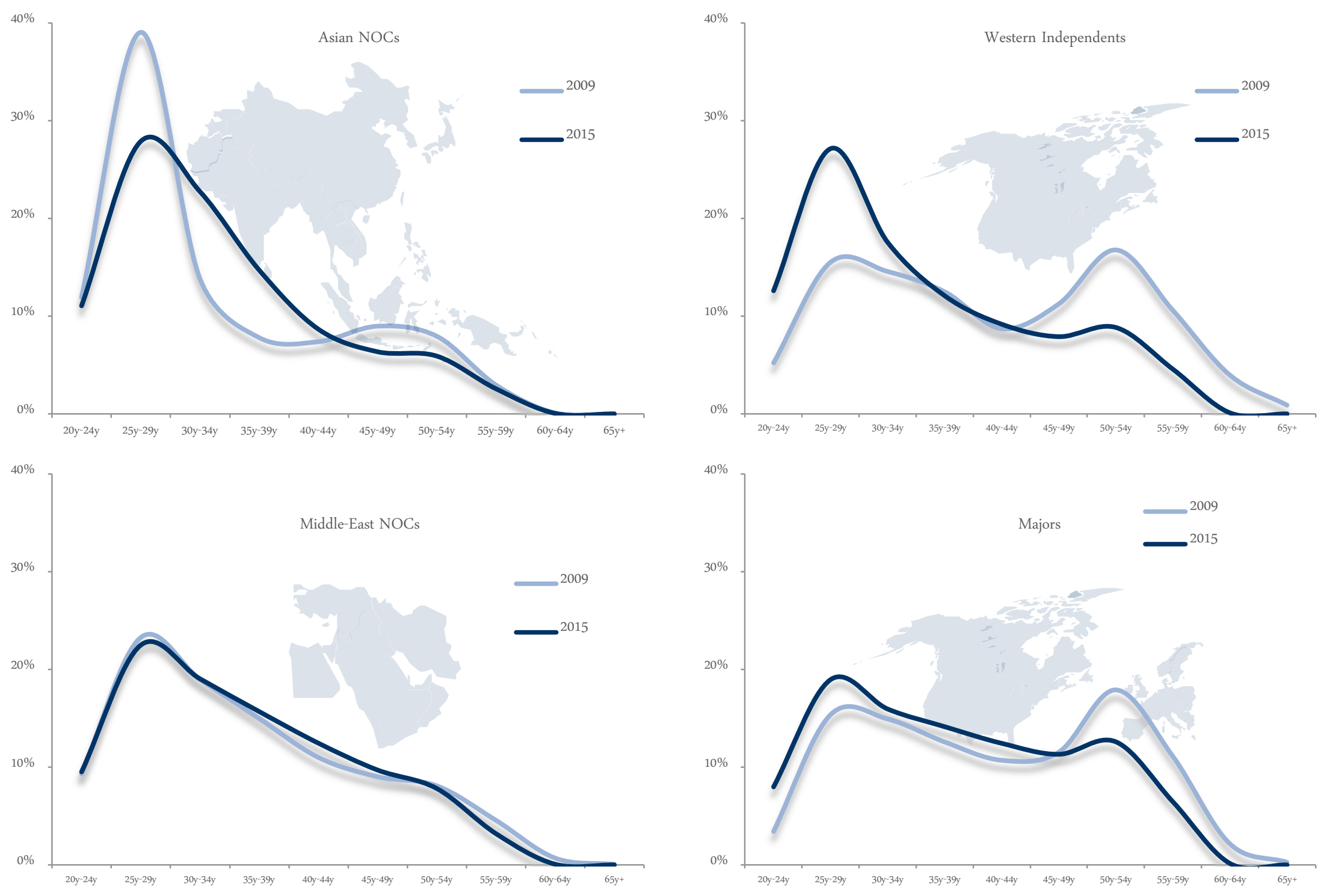

Note: From Schlumberger HR Benchmark 


\section{TIME TO AUTONOMY IS MAJOR FOCUS AREA}

Shell is implementing Graduate Recruit and Mature Hire competency building to shorten the Time to Autonomy from 9-10 years

to less than 6 years :

Shell Graduate Programme was implemented 2 years ago and is delivering new technical professionals (graduates) to "JG5" competencies in $2-3$ years.

- Shell Advanced Technical Programme will be launched this year and will bring both NTPs and Experienced Hires to "JG4" competency (autonomous operating engineers \& geoscientists) within the next 2-3 years.

Relative Time to Autonomy (years) 2008 - 2011

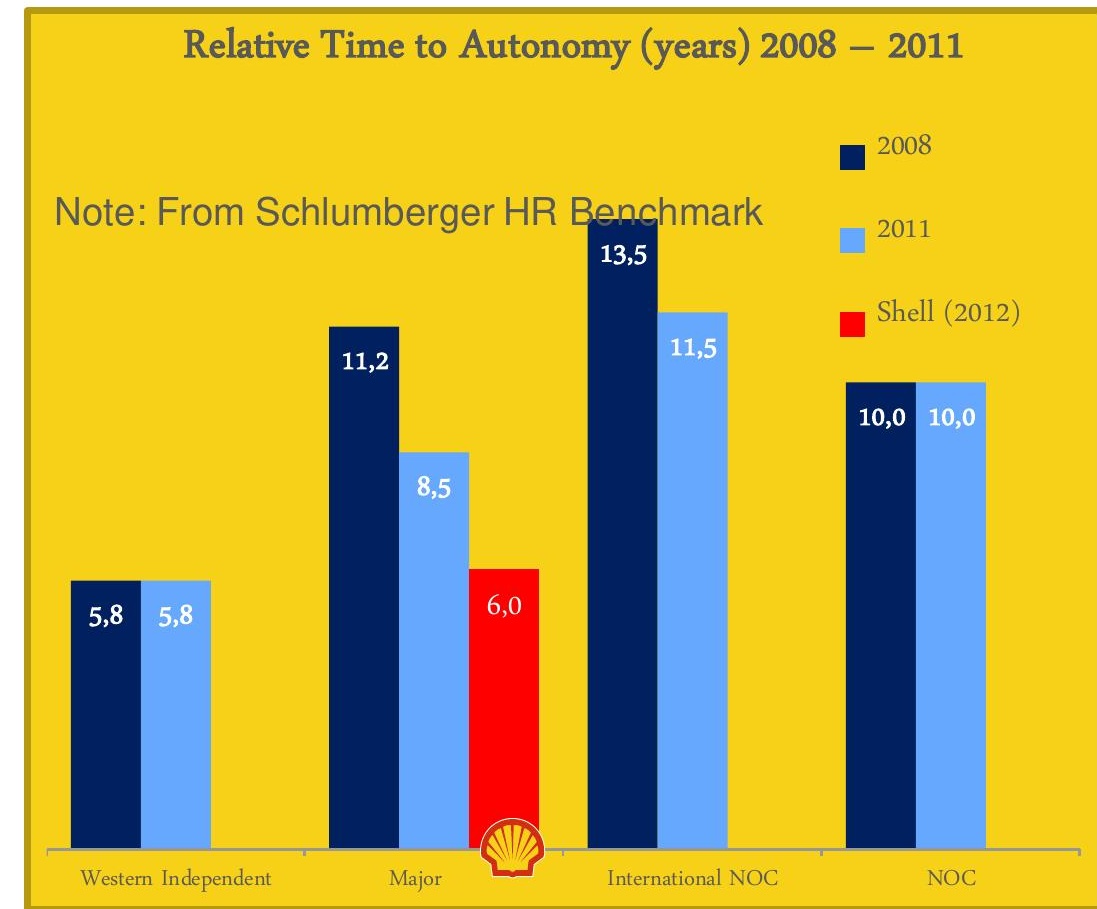




\section{GRADUATE PROGRAMME - PETROPHYSICS EXAMPLE}

\section{YEARS}

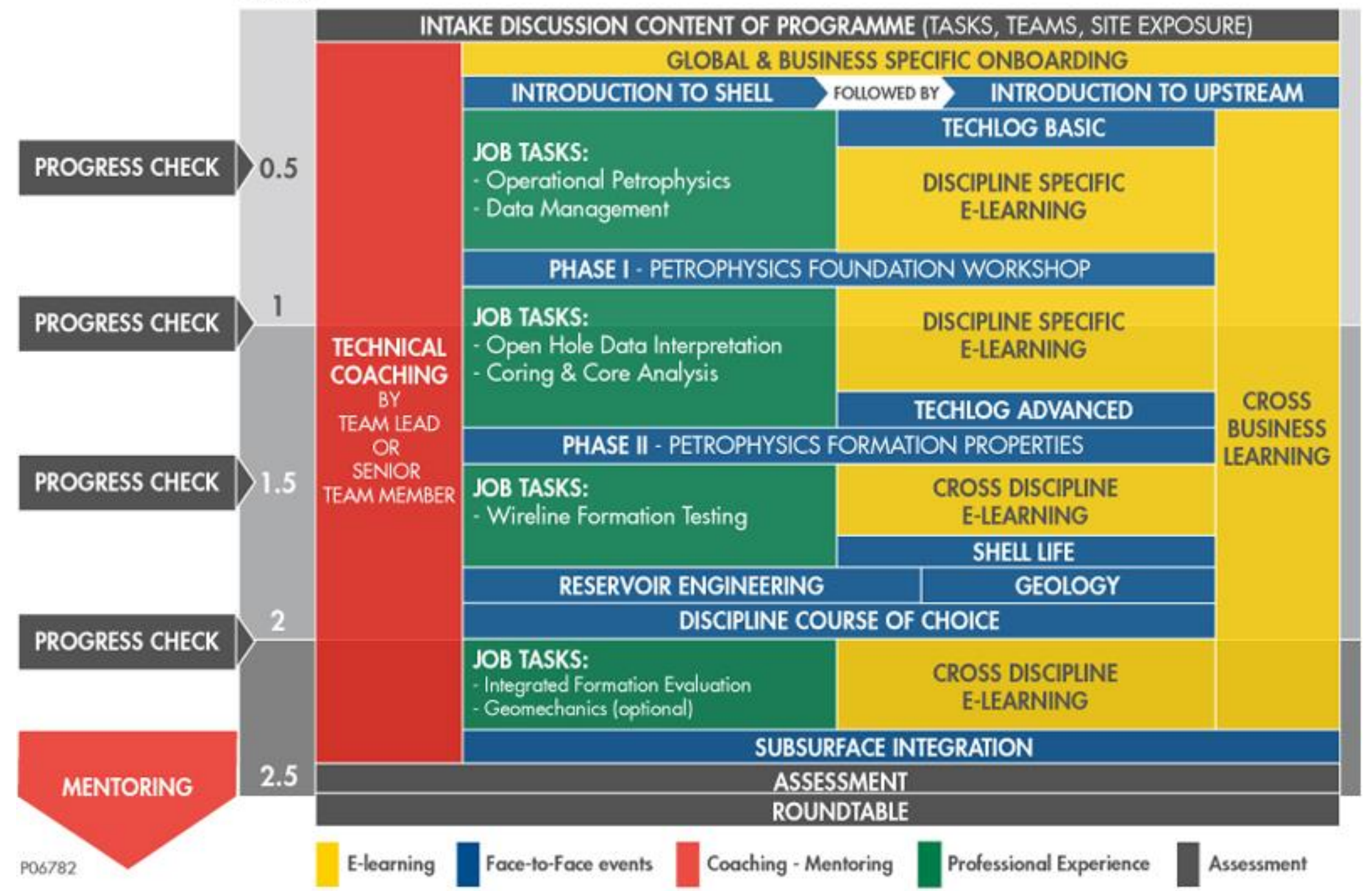

As we recruit from a mix of countries, universities and subjects, we do insist all Graduate Recruits follow the full curriculum of their discipline. By exception it is agreed to skip certain courses.

Experienced Hires get assessed and a fit-for-purpose learning programme is agreed. 


\section{THE PENTAGON FOR COMPETENCE DEVELOPMENT}

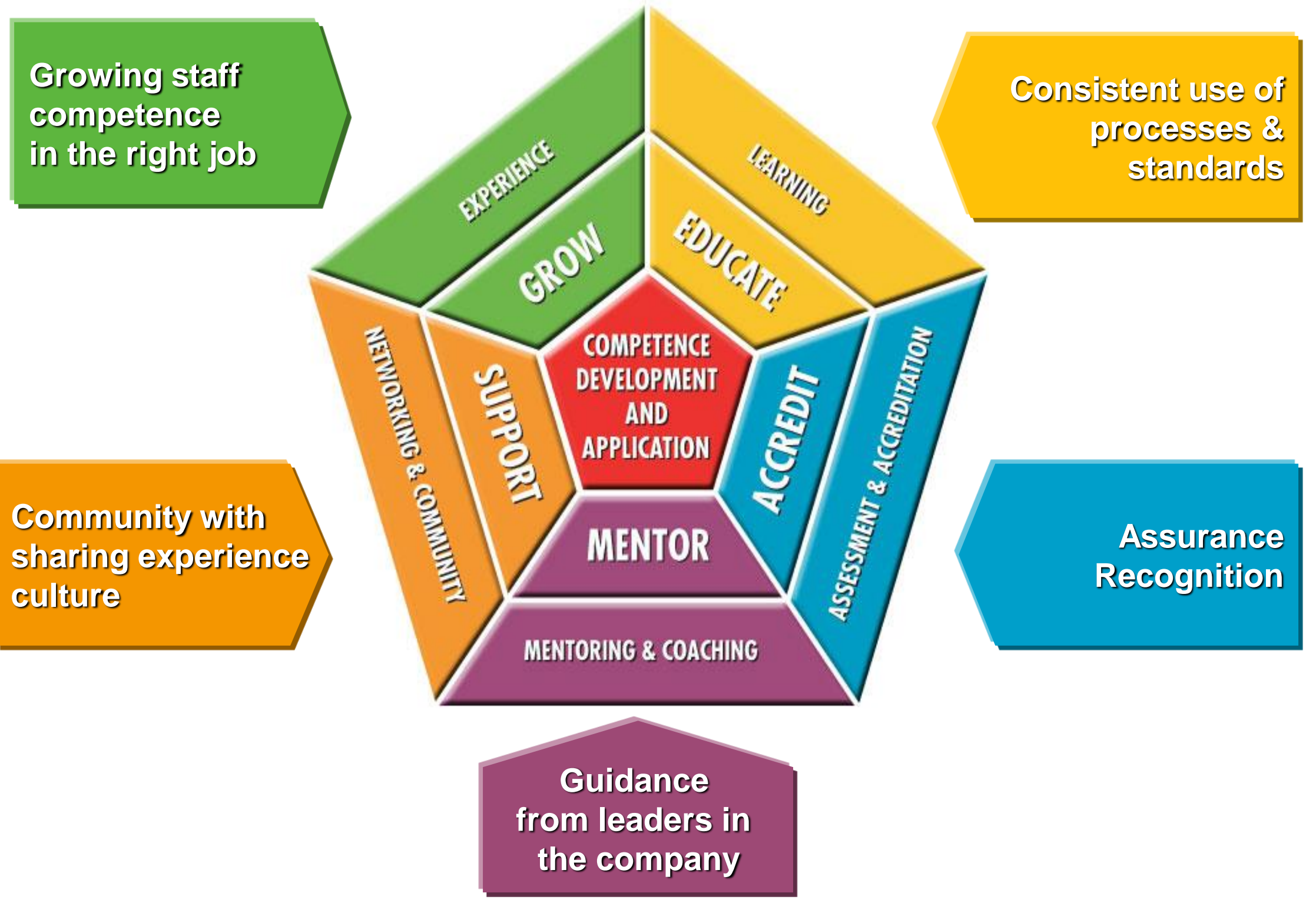




\section{COMPETENCY FRAMEWORK JOURNEY}

\section{Shell had Discipline Competency Frameworks since 10+ years:}

- 2 simplification rounds reduced from some 100 to some 55 competences per framework, including HSSE and Leadership competencies

- Individual staff competency profiles are in the central HR system. But only limited ability to do statistics on global skillpool competences database

- But largely based on self-assessment with sign-off by supervisor ... how reliable is that ?

\section{Recent Drive to change the competency management system:}

Externally: Recent industry tragedies have placed greater importance on our ability to prove our people are competent in key 'license to operate' areas
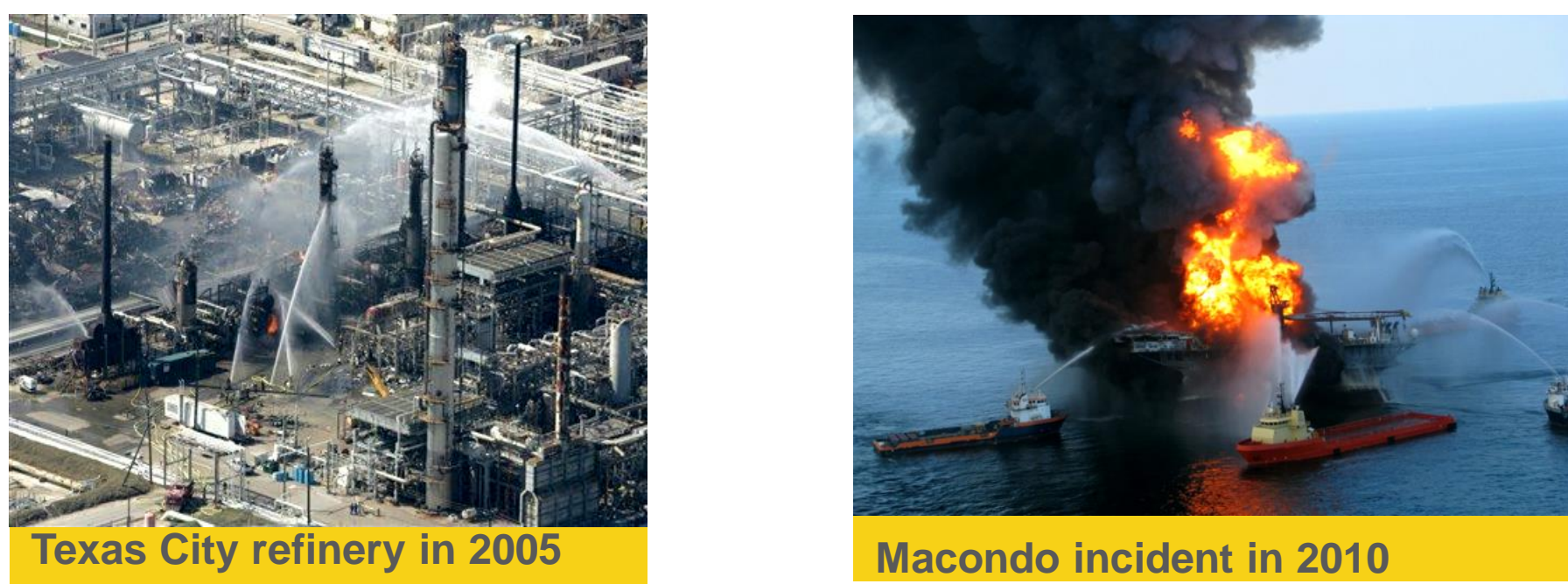

Macondo incident in 2010

Internally: Relatively large effort as we manage whole competency area in same manner 


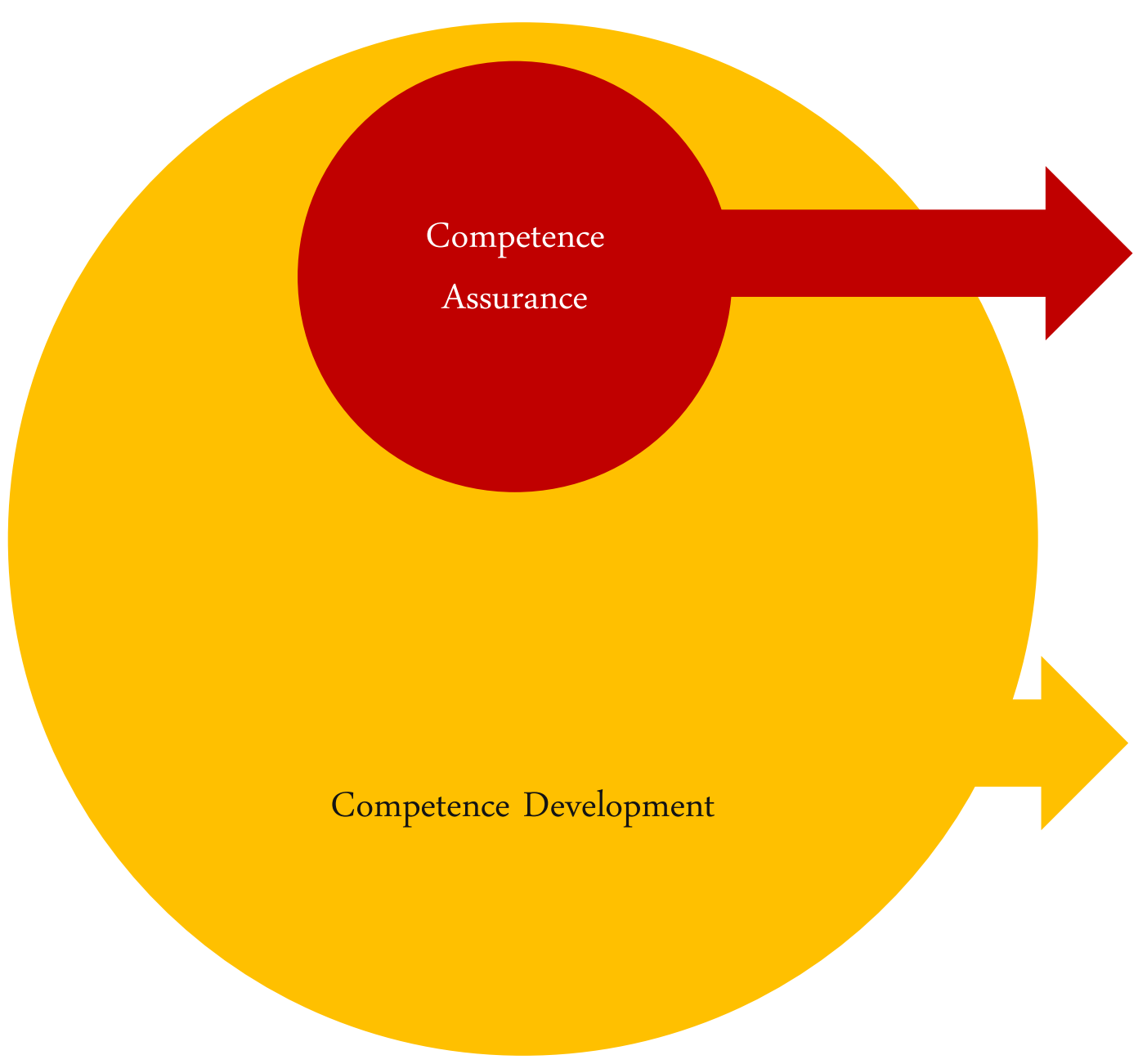

Increase Rigorous assurance and detailed tracking on:

- Operational

- HSSE

- Technical Authorities 1/2

Robust development using:

- A simplified approach for all staff in support of a strong 'Employee Value Proposition'

- Individual Development Conversations and Plans

- In role Development

- Simplified competence frameworks

- Structured capability building tools

- Targeted Learning Interventions

- Recording of professional certifications (external) where there is business need / value

\section{This new solution provides Focus and Simplicity}




\section{ASSURANCE \& ACCREDITATION IN WELLS}

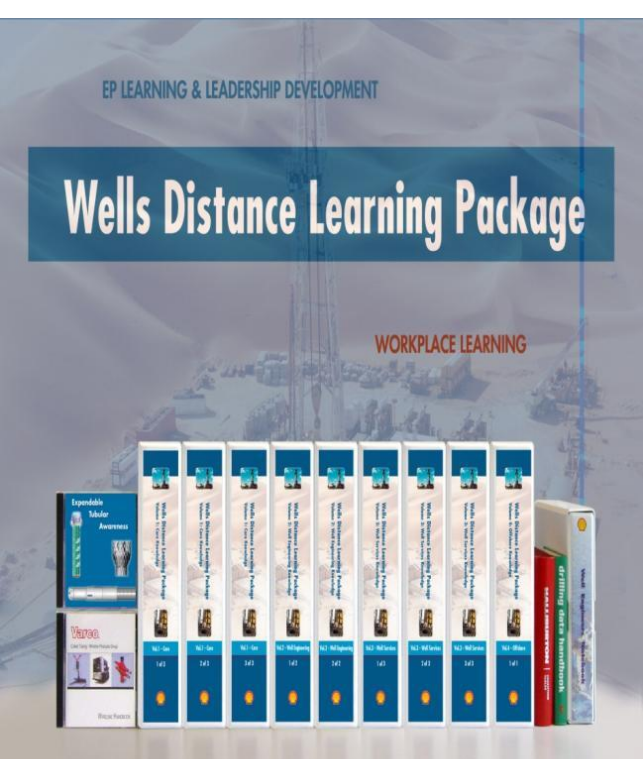

\section{Competency Development:}

- Unique to Shell and recognized across the industry

- Established 1973 start of Shell "Drilling" assessment round 1 and round 2, revised 2005 to include Well Intervention.

- Post Graduate development managed globally

- Implemented globally for all Shell Wells staff

- Syllabus includes practical field and office elements

- panel audit

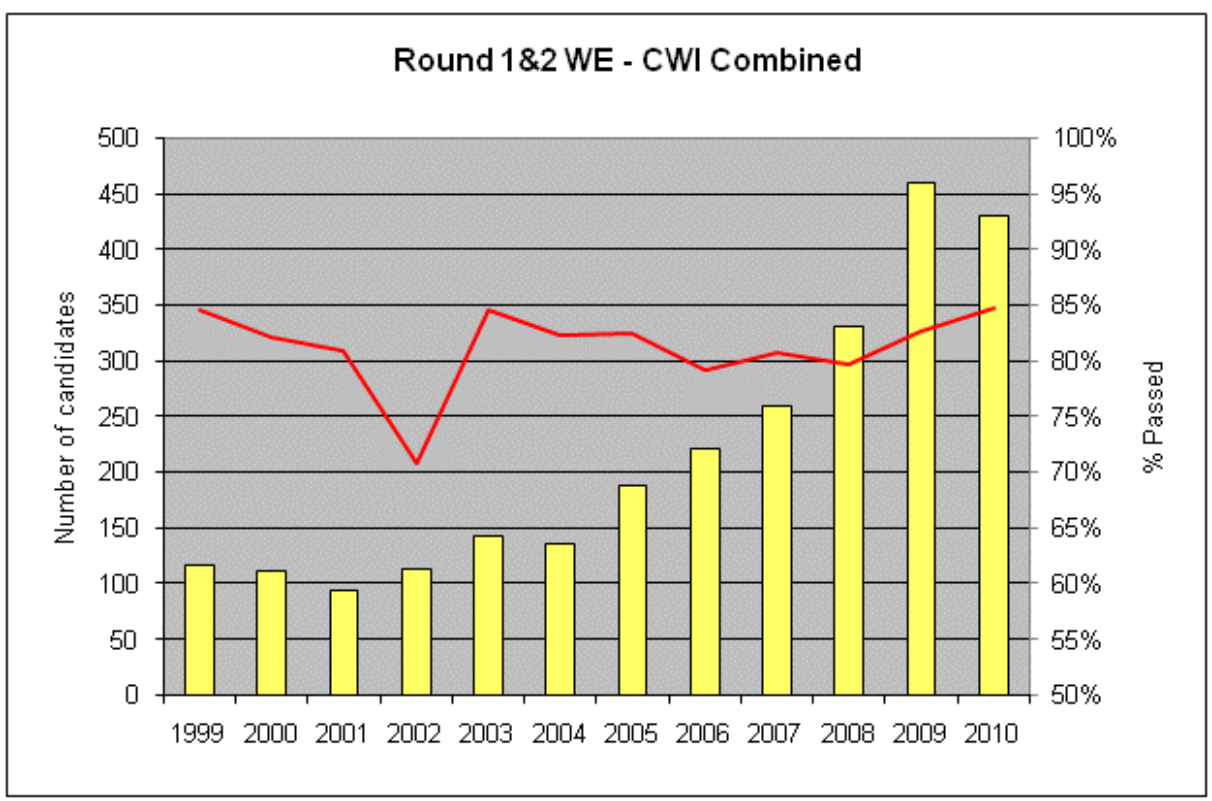

- Individuals have to pass round 1 and round 2 examinations - “Certified Engineer” after passing round 2 and global academic Masters of Science Degree level by 2 universities
- Wells Distance Learning Package is accredited to 


\section{CLASSROOM RECORDING TO GLOBAL ON-DEMAND DELIVERY}

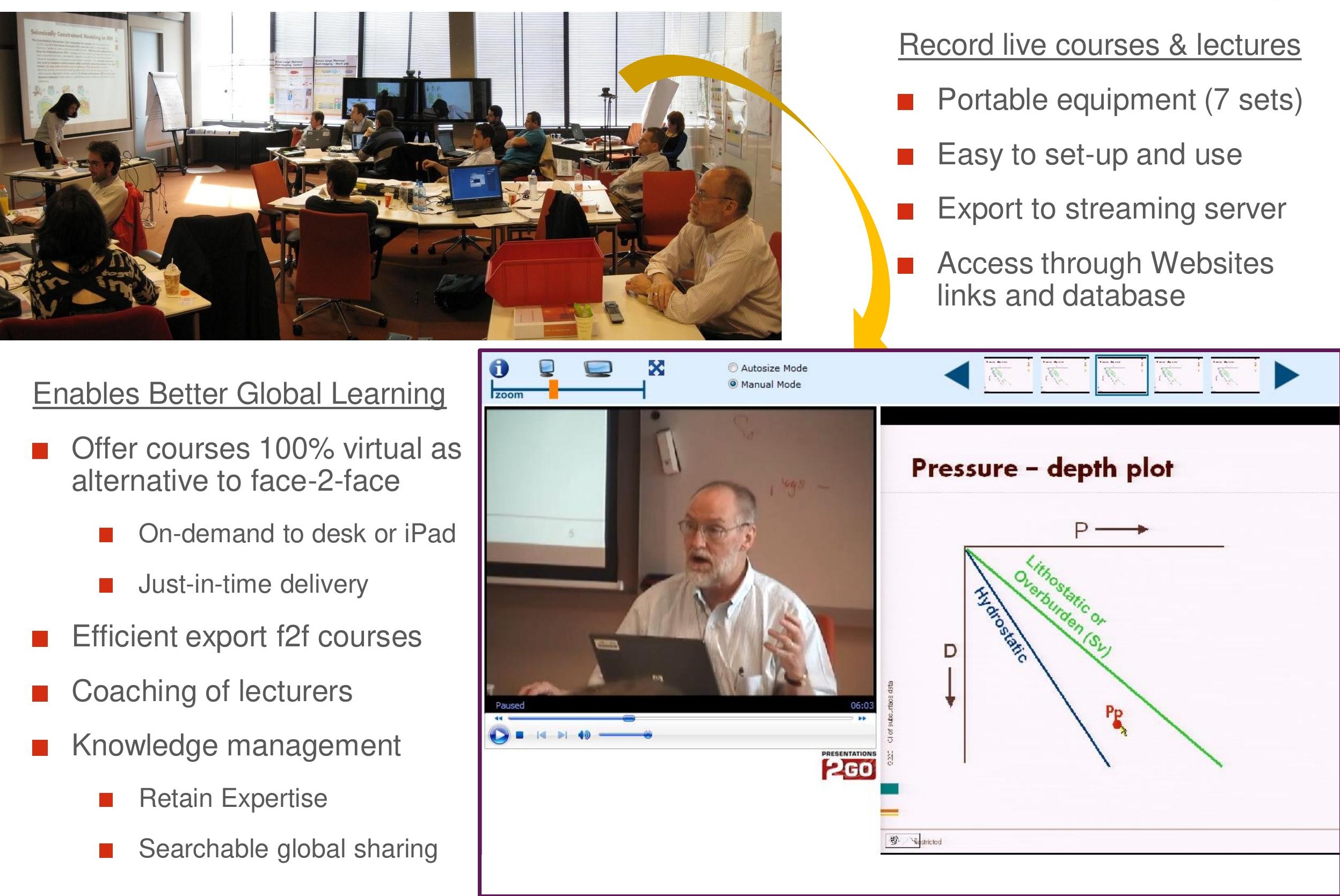




\section{Virtual Classroom using network of Collaboration Rooms}

Virtual Classroom Events:

* Up to 16 staff per location

* High intimacy environment

* Picture-in-picture

* Interactive whiteboard

* Content/speaker/participants

* 2-5 locations in 1 class
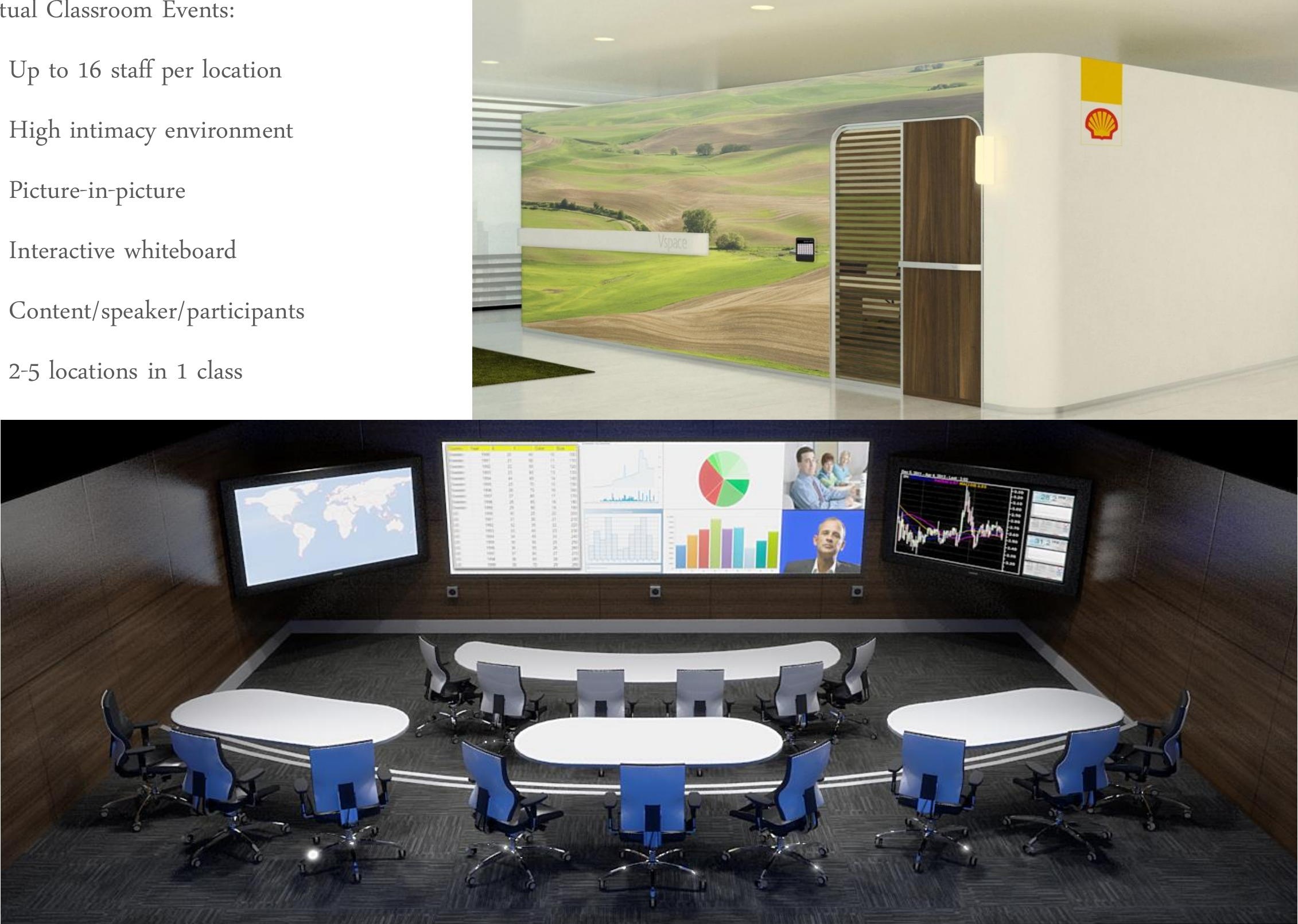


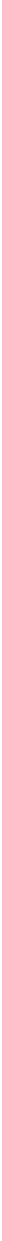

$\star \quad$ We are building 6 dedicated Learning TelePresence Rooms in learning hubs

- That can be used in conjunction with existing TelePresence Rooms in locations 
Monday Tuesday Wednesday Thursday Friday Day-time@

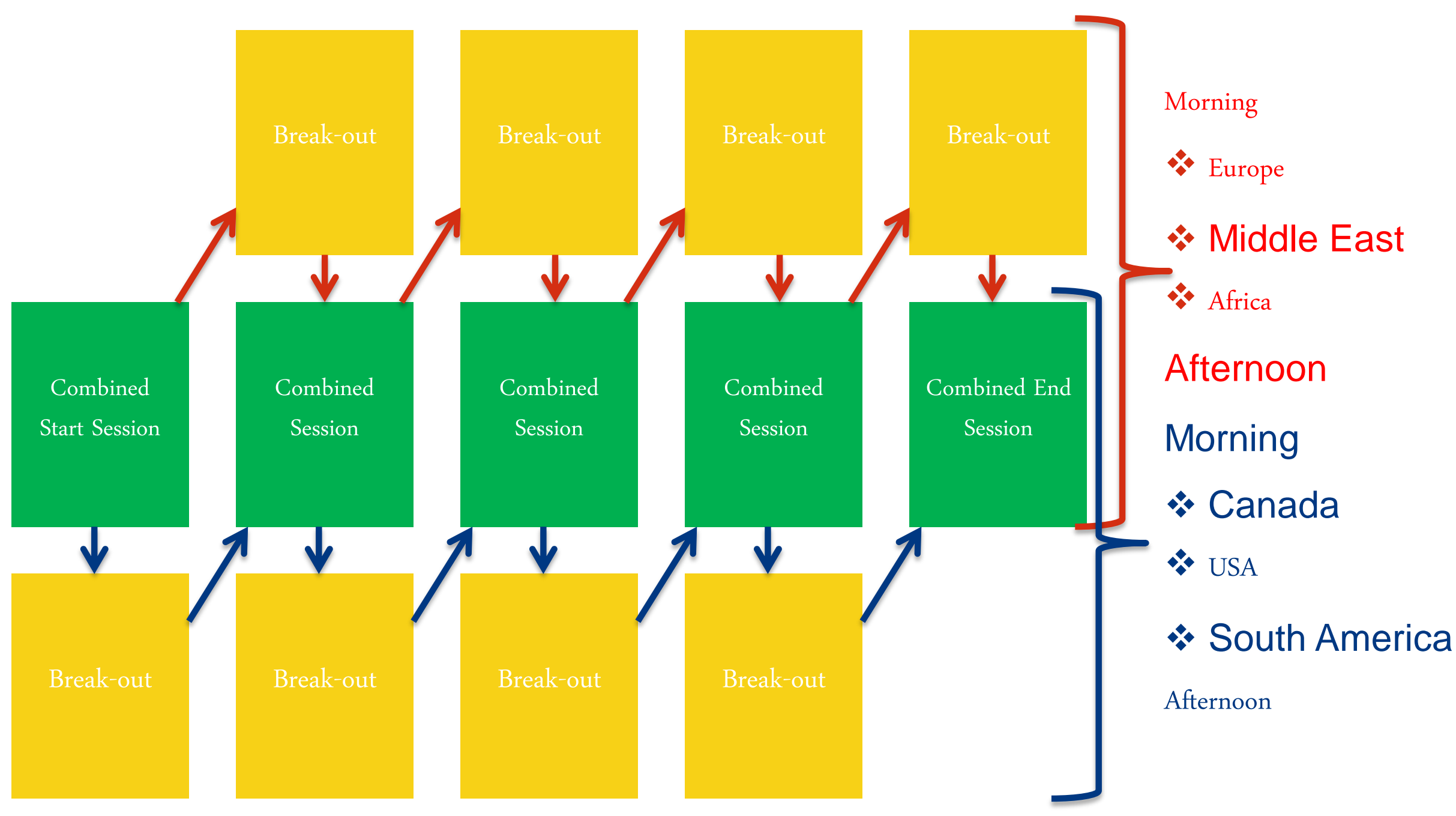




\section{WELL INTERVENTION SIMULATOR}
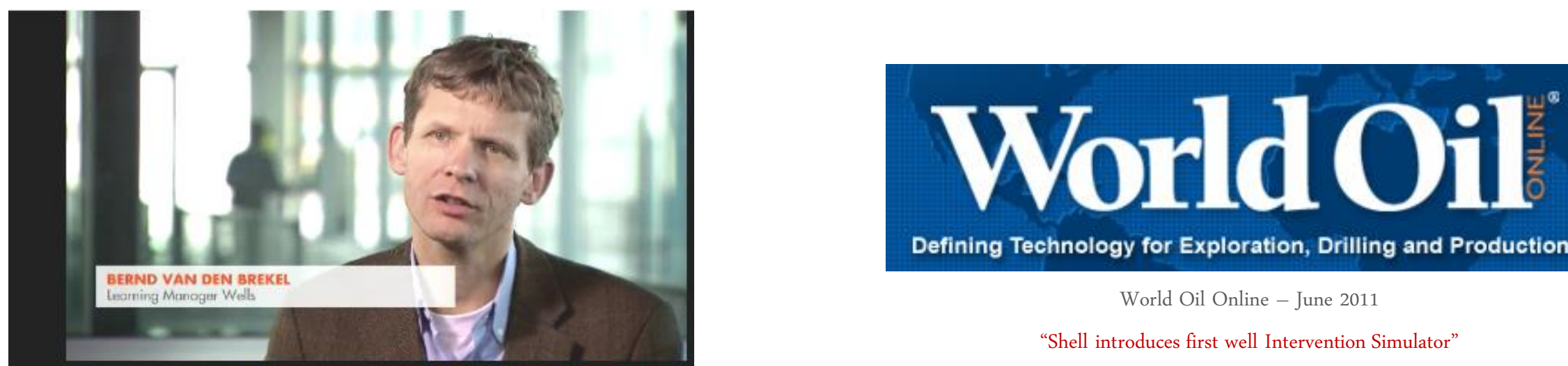

Defining Technology for Exploration, Drilling and Production

World Oil Online - June 2011

"Shell introduces first well Intervention Simulator"

“ The well intervention Simulator provides Shell with robust designs, thorough training and state-of-the-art detection"

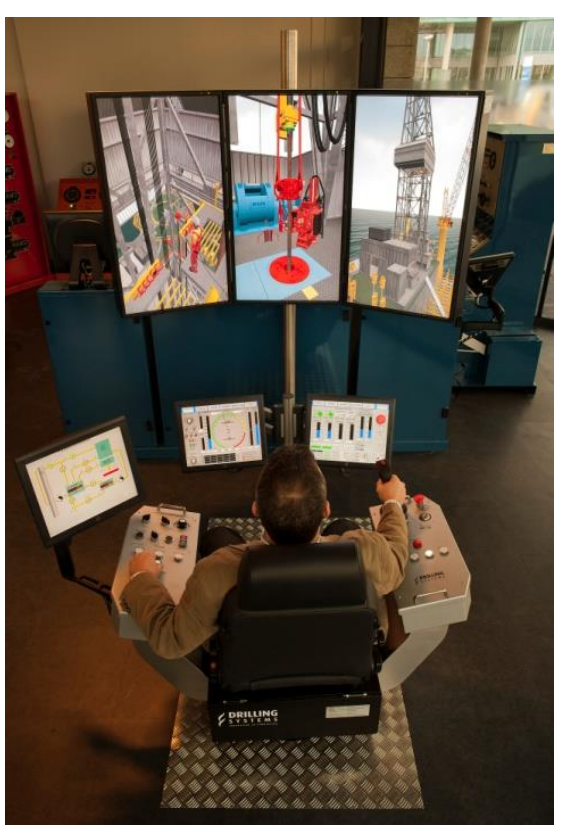

Rijswijk Well Control Training Centre

" The drilling and well intervention simulators in use during W320 Advanced Well Control training"

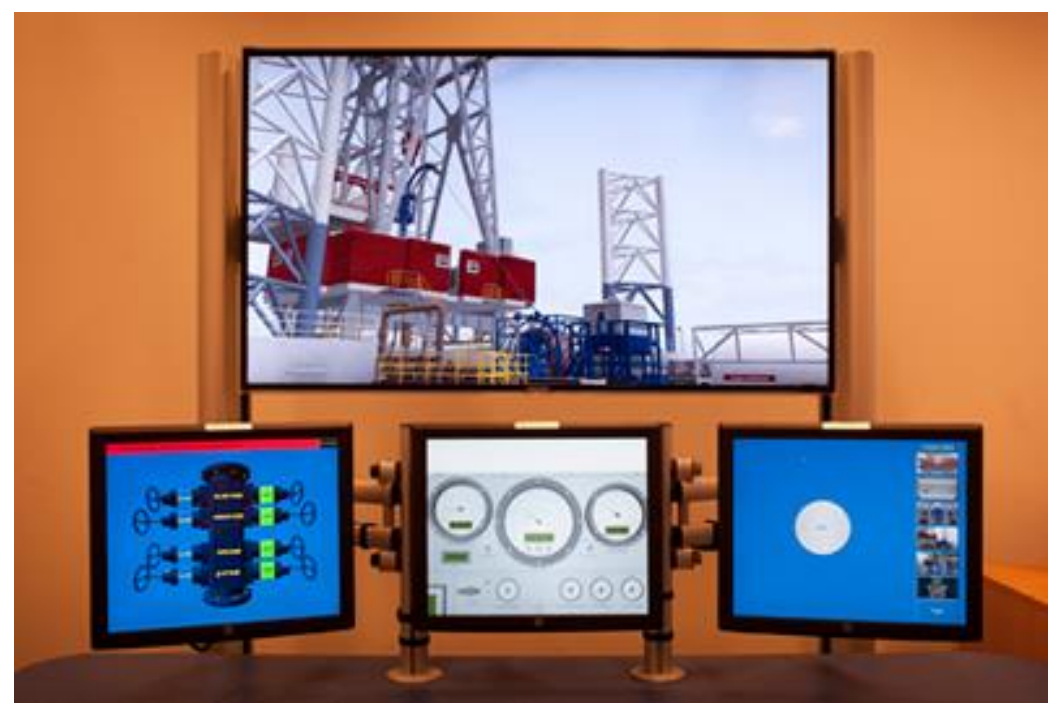




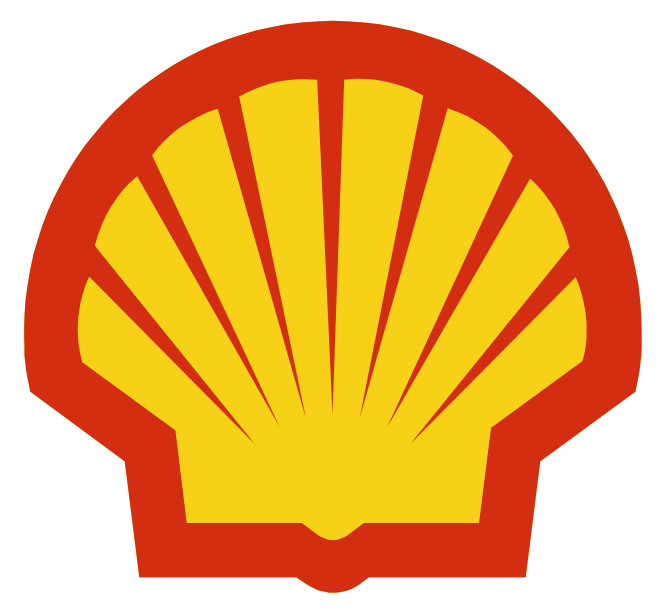

